\title{
Effect of different levels of phosphorus and potassium on yield, yield attributes and oil content of Sesame (Sesamum Indicum L.)
}

\author{
Priyadarshini, A. $\bowtie$, Umesha, C., Meshram, M.R.
}

\begin{abstract}
A field experiment was carried out during Zaid season of 2020 at Crop Research Farm, Department of Agronomy, SHUATS, Prayagraj, (U.P.). The soil of experimental site was sandy loam in texture, nearly neutral in soil reaction (pH 7.2), EC (0.34 dS/m), low in available $N(203.7 \mathrm{~kg} / \mathrm{ha})$, medium in available $P(17.2 \mathrm{~kg} / \mathrm{ha})$ and medium in available $\mathrm{K}$ $(208.8 \mathrm{~kg} / \mathrm{ha})$. The experiment was laid out in Randomized block design and having nine treatment consisted of three levels of Phosphorus (P) viz., (40, 30 and $20 \mathrm{~kg} / \mathrm{ha})$ and three levels of Potassium (K) viz., (30, 20 and $10 \mathrm{~kg} / \mathrm{ha}) \mathrm{which}$ replicated thrice and effect was observed on Gujarat Til-4 sesame variety. The result showed significantly higher yield and yield attributes viz., Number of Capsules per plant (49.80), Seeds per capsule (56.4), Test weight (3.90 g), Seed yield $(361 \mathrm{~kg} / \mathrm{ha})$, Biological yield $(2002.15 \mathrm{~kg} / \mathrm{ha})$ and quality analysis i.e. Oil content $(50.53 \%)$ were recorded maximum in application of $40 \mathrm{~kg}$ P/ha plus $20 \mathrm{~kg} \mathrm{~K} / \mathrm{ha}$.
\end{abstract}

Key words: Oil content, Sesame, Phosphorus, Potassium, Yield

\section{Introduction}

Sesame (Sesamum indicum L.) is the oldest oil seed crop and used by human beings. Sesame is variously referred to as Til, Sesamum, Beniseed, Rasi, Sim sim, Gergelim etc. Sesame is the member of family Pedaliaceae with chromosome number $2 n=26$. Sesame crop was known as "Queen of oil seed" due to the presence of stable unsaturated fatty acid (Palmitic acid (16\%), linoleic acid (18.2\%), oleic acid (18.1\%) and Stearic acid (18\%)) which causes resistance to rancidity (Uzun et al. 2008). Because of good quality characters, sesame is also used as substitute ghee for poor man's food (Pagal et al. 2017). Sesame seed is cultivated for seed purpose, which contains oil (38-54\%) and protein (18-20\%) consisting of both methionine and tryptophan, Vitamin- $\mathrm{B}_{5}$ (niacin) and minerals (P \& Ca) (Malik et al. 2003). Sesame seed also contains sesamine and sesamolin, sesamolin on hydrolysis yields sesmol, which has marked antioxidant activity, so it has a higher lifespan and is caused "Seed of immortality". White seeded sesame is extensively used in Bakery products, whereas black seeded sesame used for medicinal purposes (Jadav, 2004). Nearly $78 \%$ of sesame is used for oil

\section{Author's Address}

Sam Higginbottom University of Agriculture, Technology and Sciences, Prayagraj, Uttar Pradesh, India

E-mail.: ankitapriyadarshini10697@gmail.com extraction in India (Kalegore et al. 2018). Sesame nutrition remained very agonistic for a long time (Okpara et al. 2007). The dynamics of the nutrients in terms of their translocation, distribution and uptake in sesame plant is a crucial phase that will help in taking deciding ameliorating in its production management (Shehu et al. 2010). It will assist in the adjustment of proper package and practice for sesame crop and reduce the cost of fertilizer. Phosphorus is the major plant nutrients for enhance the crop yield. Phosphorus plays an important role in develpoment of energy-rich phosphate bond like nuclear protein, ADP and ATP and phospholipid and it is compulsory constitute of nucleic acids (DNA and RNA), nucleoprotein, amino acids, phytin, phosphatides and several coenzymes viz., thiamine, pyrophosphate and pyridoxyl phosphate (Jahan et al. 2019). Phosphorus is associated with enhanced root density proliferation, which aids in the supply of nutrients, extensive exploration and water to growing plant parts, thus rise growth and yield, as well as enhance the yield of succeeding crop and come up with resistance against diseases (Shehu et al. 2010). Phosphorus also associates with energy transfer metabolic processes and basic reaction of transformation of sugars, photosynthesis, starch and 


\section{Priyadarshini et al.}

nutrient movements in the plant. It also promotes extensive root system thereby enabling plant to take out moisture and mineral nutrition optimally (Adisu et al. 2020). Potassium enhances the yield and quality of agricultural produce and products and enhances the capability of plants to resists diseases, insect attacks, cold and drought stresses (Ahmad et al. 2018). Potassium shows a very important character in the activation of enzymes (Younis et al. 2020). Potassium helps in the development of a strong and healthy root system. Potassium shows an essential role in many metabolic actions in plants. Potash is involved in the transport of the products of photosynthesis to the pods and transformation into oil (Jat et al. 2017). A good supply of potassium leads to an increase in photosynthesis, which is actively concerned with the process of sugar formation and translocation of starch as well as photosynthesis. In view of these investigations, the experiment was under taken to find out suitable phosphorus and potassium levels on the application for maximizing the yield, quantity and quality of sesame under eastern Uttar Pradesh conditions.

\section{Materials and Methods}

The experiment entitled "Effect of different levels of Phosphorus and Potassium on Yield, Yield attributes and Oil content of Sesame (Sesamum indicum L.)", was held at Crop Research Farm, Sam Higginbottom University of Agriculture, Technology and Sciences, Prayagraj. The experiment was carried out during Zaid season of 2020 under irrigated condition at Crop Research farm, Department of Agronomy, Naini Agricultural Institute, SHUATS, Prayagraj (Allahabad) which is located at $25^{\circ} 24^{\prime} 42^{\prime \prime} \mathrm{N}$ latitude, $81^{\circ} 50^{\prime} 56^{\prime \prime} \mathrm{E}$
Longitude (Fig.1) and $98 \mathrm{~m}$ altitude above the mean sea level. It has a tropical climate with temperature ranges between $43^{\circ} \mathrm{C}-47^{\circ} \mathrm{C}$. The Experiment was carried out in Randomized Block Design having nine treatment consisted of Phosphors levels viz., (40, 30 and $20 \mathrm{~kg} / \mathrm{ha})$ and Potassium levels viz., (30, 20 and $10 \mathrm{~kg} / \mathrm{ha})$ which replicated thrice on Gujarat Til-4 sesame variety. On the basis of treatment details, treatment combination are $\mathrm{T}_{1}$ - Phosphorus (P)@ $90 \mathrm{~kg} / \mathrm{ha}+$ Potassium (K)@30kg/ha, T2- Phosphorus (P)@ $40 \mathrm{~kg} / \mathrm{ha}+$ Potassium (K) @ $20 \mathrm{~kg} / \mathrm{ha}, \mathrm{T}_{3^{-}}$ Phosphorus (P)@40kg/ha+Potassium (K)@10 kg/ha, T $4^{-}$Phosphorus (P)@30 kg/ha + Potassium (K)@30kg/ha, T $5^{-}$Phosphorus (P)@30kg/ha + Potassium (K)@20kg/ha, T $6^{-}$Phosphorus (P)@ $30 \mathrm{~kg} / \mathrm{ha}+$ Potassium (K) @ $10 \mathrm{~kg} / \mathrm{ha}, \mathrm{T}_{7^{-}}$ Phosphorus (P)@20kg/ha+Potassium (K)@30 kg/ha, T $8^{-}$Phosphorus (P)@20 kg/ha + Potassium (K)@20kg/ha, T.-Phosphorus (P)@20kg/ha + Potassium (K)@10 kg/ha. Sowing was done by line sowing method with row spacing $30 \mathrm{~cm}$ and plant spacing $10 \mathrm{~cm}$. The commended cultural practices were under taken as per recommendation. Hand weeding was done at 15 and 30 Days after sowing (DAS). Data on yield attributes viz., Number of Capsules per plant, Number of Seeds per capsule, Test weight (g), Seed yield ( $\mathrm{kg} / \mathrm{ha})$, Biological yield ( $\mathrm{kg} / \mathrm{ha})$ and Quality analysis viz., Oil content (\%) were analyzed by analysis of variance (ANOVA) (Gomez and Gomez 1984). The data collected from the experiment at various growth stages and at the time of harvest was subjected to statistical analysis using Dry soft ICRISAT software. The level of significance used in F-test was $\mathrm{P}=0.05$. Critical difference values were calculated wherever F-test was found significant.
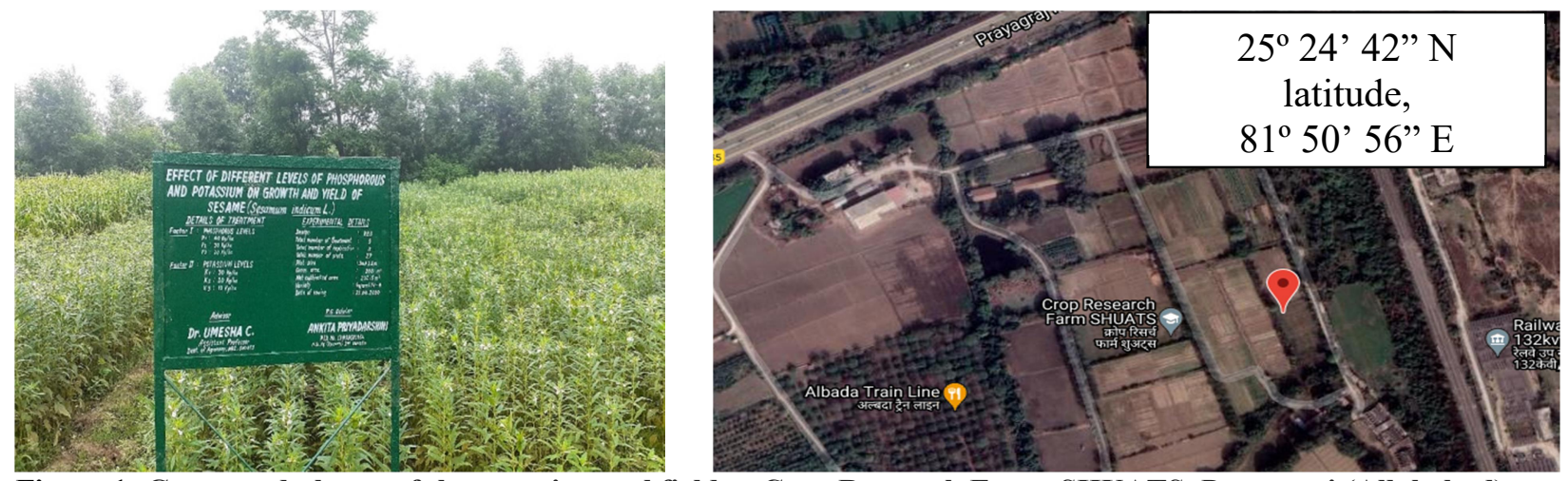

Figure 1: Geotagged photos of the experimental field at Crop Research Farm, SHUATS, Prayagraj (Allahabad) 


\section{Results and Discussion Plant height}

Data on plant height by different treatment combinations are presented in Table 1 . The plant height was increased with the improvement in crop stage, without consideration of the treatment and reached a maximum height at the time of harvest. The plant height of sesame was recorded at 15, 30, 45, 60 DAS and at the time of harvest differed significantly with different treatment combinations. Data on 30, 45, 60 DAS and at time of harvest shown significantly influenced among all treatments, increase with maximum plant height $(29.61 \mathrm{~cm}, 78.53 \mathrm{~cm}, 116.09 \mathrm{~cm}$ and $116.91 \mathrm{~cm})$ were recorded in application of Phosphorus (P) @ $40 \mathrm{~kg} / \mathrm{ha}+$ Potassium (K) @ $20 \mathrm{~kg} / \mathrm{ha}$ as compared to other treatment combinations respectively. $\mathrm{T}_{1}$ and $\mathrm{T}_{3}$ were statistically at par with $\mathrm{T}_{2}$ at $30 \mathrm{DAS}$, 60 DAS and at harvest, and only $\mathrm{T}_{1}$ was statistically at par with $\mathrm{T}_{2}$ at $45 \mathrm{DAS}$. The data on plant height at 15 DAS shown there is no significant dissimilarity among the treatments. The progressive increase in levels of phosphorus i.e. Phosphorus (P) (a) $40 \mathrm{~kg} / \mathrm{ha}$ significantly enhanced the growth attributing characters of sesame viz., plant height was similar with the results by Jahan et al. (2019) in Sesame. Phosphorus work as catalysis in the conversion of many key biochemical reactions energy storage and transformation processes in plants. These results are in similarity with the findings of Rahman et al. (2008) and Chakraborty (2013). The increase in plant height could partly be attributed due to the beneficial effect of potassium fertilizer. This is in agreement with the findings of Jadav (2004) and Bhosale (2009) in sesame.

\section{Number of branches per plant}

The data on number of branches per plant at 45, 60 and 75 DAS influenced by different treatment in sesame are presented in Table 2. The number of branches of sesame was recorded at 45, 60 and at harvest differed significantly with different treatment combinations. Data on 45 DAS, 60 DAS and at the time of harvest shown significantly increase with higher number of branches per plant $(2.73,3.73$ and 3.73$)$ respectively were recorded in application of Phosphorus (P) @ $40 \mathrm{~kg} / \mathrm{ha}+$ Potassium (K)@20 kg/ha as compared to other treatment combinations. $\mathrm{T}_{1}$ was statistically on par with $T_{2}$ at 45 DAS and at harvest and both $T_{1}$ and
$T_{3}$ were statistically at par with $T_{2}$ at 60 DAS. The progressive increase in levels of phosphorus i.e. Phosphorus (P)@40 kg/ha significantly enhanced the growth attributing characters of sesame i.e. number of primary and secondary branches per plant was reported by Jahan et al. (2019) and Shelke et al. (2014) in Sesame. The effect of potassium on growth parameters may be due to augment of cell expansion and cell division. These results are found similar to the results of Thakur et al., (2015) in sesame.

\section{Leaf area $\left(\mathrm{cm}^{2}\right)$}

Phosphorus and Potassium levels had significantly influenced mean leaf area/plant at all stages of crop growth except at the time of harvest. The effect of different treatment on leaf area at 15, 30, 45, 60 and at harvest are presented in Table 3. Data on 30, 45, 60 DAS and at harvest, the maximum leaf area $\left(227.80 \mathrm{~cm}^{2}, 2074.57 \mathrm{~cm}^{2}, 2270.49 \mathrm{~cm}^{2}\right.$ and $2568.70 \mathrm{~cm}^{2}$ ) were recorded by application of Phosphorus (P)@40kg/ha + Potassium (K)@20 $\mathrm{kg} / \mathrm{ha}$ which was significantly superior overall treatment combinations respectively. $T_{1}, T_{3}$ and $T_{5}$ were statistically on par with $\mathrm{T}_{2}$ at $45,60 \mathrm{DAS}$ and at harvest, and $T_{1}$ and $T_{3}$ were statistically on par with $\mathrm{T}_{2}$ at $30 \mathrm{DAS}$. The data on leaf area at $15 \mathrm{DAS}$ shown there is no significant difference among the treatments. Optimum moisture in root zone which favours uptake of phosphorus; resulting in better growth of the crop was parallelism with De et al. (2013) and Unde et al. (2017). The increase in levels of potassium also significantly increased the leaf area of sesame due to uptake and beneficial crop activity, similar results was also conformity by Sarkar and Pal (2005) in sesame.

\section{Leaf area index}

Effect of different treatment on leaf area index at $15,30,45,60$ DAS and at harvest time are presented in Table 4. and the data pertaining to the leaf area index were obtained lowest at 15 DAS and then it increases with development of crop growth stages. Data on 30, 45, 60 DAS and at harvest time, the maximum leaf area index $(0.76$, $6.58,7.57$ and 8.56) were recorded by application of Phosphorus (P)@40kg/ha + Potassium (K)@ $20 \mathrm{~kg} / \mathrm{ha}$ which was significantly superior overall treatment combinations respectively. The data on leaf area index at 15 DAS shown there is no significant dissimilarity among the treatments. The progressive increase in levels of phosphorus i.e. 
Priyadarshini et al.

Table 1: Influence of Phosphorus and Potassium levels on Plant height of Sesame

\begin{tabular}{|r|l|l|l|l|l|}
\hline \multirow{2}{*}{ Treatments } & \multicolumn{5}{|c|}{ Plant height (cm) } \\
\cline { 2 - 6 } & \multicolumn{1}{|c|}{ 15 DAS } & \multicolumn{1}{|c|}{ 30 DAS } & 45 DAS & \multicolumn{1}{|c|}{ D0 DAS } & \multicolumn{1}{|c|}{ D5 DAS } \\
\hline $\mathbf{1 .} 40 \mathrm{~kg} \mathrm{P} / \mathrm{ha}+30 \mathrm{~kg} \mathrm{~K} / \mathrm{ha}$ & 13.43 & 27.27 & 70.73 & 110.55 & 112.07 \\
\hline $\mathbf{2 .} 40 \mathrm{~kg} \mathrm{P} / \mathrm{ha}+20 \mathrm{~kg} \mathrm{~K} / \mathrm{ha}$ & 13.59 & 29.61 & 78.53 & 116.09 & 116.91 \\
\hline $\mathbf{3 .} \quad 40 \mathrm{~kg} \mathrm{P} / \mathrm{ha}+10 \mathrm{~kg} \mathrm{~K} / \mathrm{ha}$ & 13.12 & 26.61 & 66.59 & 108.08 & 109.39 \\
\hline $\mathbf{4 .} \quad 30 \mathrm{~kg} \mathrm{P} / \mathrm{ha}+30 \mathrm{~kg} \mathrm{~K} / \mathrm{ha}$ & 11.81 & 24.43 & 60.58 & 103.57 & 105.83 \\
\hline $\mathbf{5 .} \quad 30 \mathrm{~kg} \mathrm{P} / \mathrm{ha}+20 \mathrm{~kg} \mathrm{~K} / \mathrm{ha}$ & 12.34 & 25.76 & 61.05 & 107.48 & 108.33 \\
\hline $\mathbf{6 .} \quad 30 \mathrm{~kg} \mathrm{P} / \mathrm{ha}+10 \mathrm{~kg} \mathrm{~K} / \mathrm{ha}$ & 11.39 & 23.12 & 60.26 & 103.20 & 104.36 \\
\hline $\mathbf{7 .} \quad 20 \mathrm{~kg} \mathrm{P} / \mathrm{ha}+30 \mathrm{~kg} \mathrm{~K} / \mathrm{ha}$ & 11.71 & 23.93 & 61.47 & 94.84 & 95.55 \\
\hline $\mathbf{8 .} \quad 20 \mathrm{~kg} \mathrm{P} / \mathrm{ha}+20 \mathrm{~kg} \mathrm{~K} / \mathrm{ha}$ & 12.07 & 25.63 & 64.72 & 101.38 & 104.43 \\
\hline $\mathbf{9 .} \quad 20 \mathrm{~kg} \mathrm{P} / \mathrm{ha}+10 \mathrm{~kg} \mathrm{~K} / \mathrm{ha}$ & 11.51 & 22.62 & 59.15 & 93.30 & 94.09 \\
\hline $\mathrm{SEm} \pm$ & 0.69 & 1.22 & 3.39 & 2.73 & 2.68 \\
\hline $\mathrm{CD}(\mathrm{P}=0.05)$ & - & 3.65 & 10.17 & 8.18 & 8.02 \\
\hline
\end{tabular}

Table 2: Influence of Phosphorus and Potassium levels on Number of Branches/plant of Sesame

\begin{tabular}{|c|l|l|l|}
\hline Treatments & \multicolumn{3}{l|}{ No. of Branches per Plant } \\
\cline { 3 - 4 } & 45 DAS & 60 DAS & 75 DAS \\
\hline $\mathbf{1 .} 40 \mathrm{~kg} \mathrm{P} / \mathrm{ha}+30 \mathrm{~kg} \mathrm{~K} / \mathrm{ha}$ & 2.20 & 2.67 & 3.13 \\
\hline $\mathbf{2} .40 \mathrm{~kg} \mathrm{P} / \mathrm{ha}+20 \mathrm{~kg} \mathrm{~K} / \mathrm{ha}$ & 2.73 & 3.73 & 3.73 \\
\hline $\mathbf{3 .} 40 \mathrm{~kg} \mathrm{P} / \mathrm{ha}+10 \mathrm{~kg} \mathrm{~K} / \mathrm{ha}$ & 1.80 & 2.60 & 2.73 \\
\hline $\mathbf{4} \quad 30 \mathrm{~kg} \mathrm{P} / \mathrm{ha}+30 \mathrm{~kg} \mathrm{~K} / \mathrm{ha}$ & 1.60 & 2.27 & 2.60 \\
\hline $\mathbf{5 .} 30 \mathrm{~kg} \mathrm{P} / \mathrm{ha}+20 \mathrm{~kg} \mathrm{~K} / \mathrm{ha}$ & 1.87 & 2.40 & 2.67 \\
\hline $\mathbf{6 .} 30 \mathrm{~kg} \mathrm{P} / \mathrm{ha}+10 \mathrm{~kg} \mathrm{~K} / \mathrm{ha}$ & 1.53 & 2.20 & 2.53 \\
\hline $\mathbf{7 .} 20 \mathrm{~kg} \mathrm{P} / \mathrm{ha}+30 \mathrm{~kg} \mathrm{~K} / \mathrm{ha}$ & 1.67 & 2.33 & 2.47 \\
\hline $\mathbf{8 .} 20 \mathrm{~kg} \mathrm{P} / \mathrm{ha}+20 \mathrm{~kg} \mathrm{~K} / \mathrm{ha}$ & 1.80 & 2.40 & 2.67 \\
\hline $\mathbf{9} .20 \mathrm{~kg} \mathrm{P} / \mathrm{ha}+10 \mathrm{~kg} \mathrm{~K} / \mathrm{ha}$ & 1.60 & 2.07 & 2.27 \\
\hline $\mathrm{SEm} \pm$ & 0.22 & 0.23 & 0.27 \\
\hline $\mathrm{CD}(\mathrm{P}=0.05)$ & 0.66 & 0.69 & 0.80 \\
\hline
\end{tabular}

Table 3: Influence of Phosphorus and Potassium levels on leaf area in Sesame

\begin{tabular}{|c|c|c|c|c|c|}
\hline \multirow[t]{2}{*}{ Treatments } & \multicolumn{5}{|c|}{ Leaf area $\left(\mathrm{cm}^{2}\right)$} \\
\hline & 15 DAS & 30 DAS & 45 DAS & 60 DAS & 75 DAS \\
\hline 1. $40 \mathrm{~kg} \mathrm{P} / \mathrm{ha}+30 \mathrm{~kg} \mathrm{~K} / \mathrm{ha}$ & 50.79 & 224.55 & 1972.91 & 2196.02 & 2200.12 \\
\hline 2. $40 \mathrm{~kg} \mathrm{P} / \mathrm{ha}+20 \mathrm{~kg} \mathrm{~K} / \mathrm{ha}$ & 54.78 & 227.80 & 2074.57 & 2270.49 & 2568.70 \\
\hline 3. $\quad 40 \mathrm{~kg} \mathrm{P} / \mathrm{ha}+10 \mathrm{~kg} \mathrm{~K} / \mathrm{ha}$ & 44.99 & 222.82 & 1798.18 & 1974.22 & 2192.17 \\
\hline 4. $30 \mathrm{~kg} \mathrm{P} / \mathrm{ha}+30 \mathrm{~kg} \mathrm{~K} / \mathrm{ha}$ & 47.21 & 148.10 & 1407.41 & 1741.69 & 1747.82 \\
\hline 5. $30 \mathrm{~kg} \mathrm{P} / \mathrm{ha}+20 \mathrm{~kg} \mathrm{~K} / \mathrm{ha}$ & 50.58 & 168.15 & 1636.20 & 1785.89 & 2121.41 \\
\hline 6. $30 \mathrm{~kg} \mathrm{P} / \mathrm{ha}+10 \mathrm{~kg} \mathrm{~K} / \mathrm{ha}$ & 37.31 & 107.14 & 1376.72 & 1695.73 & 1569.66 \\
\hline 7. $20 \mathrm{~kg} \mathrm{P} / \mathrm{ha}+30 \mathrm{~kg} \mathrm{~K} / \mathrm{ha}$ & 28.49 & 105.31 & 1018.28 & 1282.76 & 1435.49 \\
\hline 8. $20 \mathrm{~kg} \mathrm{P} / \mathrm{ha}+20 \mathrm{~kg} \mathrm{~K} / \mathrm{ha}$ & 46.22 & 167.95 & 1093.71 & 1434.21 & 1625.35 \\
\hline 9. $20 \mathrm{~kg} \mathrm{P} / \mathrm{ha}+10 \mathrm{~kg} \mathrm{~K} / \mathrm{ha}$ & 26.94 & 91.11 & 927.09 & 946.77 & 1199.31 \\
\hline $\mathrm{SEm} \pm$ & 6.76 & 16.97 & 57.43 & 172.17 & 182.5 \\
\hline $\mathrm{CD}(\mathrm{P}=0.05)$ & - & 50.87 & 506.40 & 516.16 & 547.27 \\
\hline
\end{tabular}

Phosphorus (P)@40 kg/ha significantly enhanced the significantly increased the leaf area index of sesame growth attributing characters of sesame i.e. leaf area plant. These results are similar to Sarkar and Pal index was ultimately maximum in sesame (Chang et (2005) in sesame. al. (2005)). The increase in levels of potassium also 
Yield and Yield attributes

Observations regarding yield and yield attributes like Number of capsules per plant (No.), Number of seeds per capsules (No.) and Test weight (g), Seed yield $(\mathrm{kg} / \mathrm{ha})$ and Biological yield $(\mathrm{kg} / \mathrm{ha})$ of sesame depicted in Table 5.

Number of capsules per plant

The number of capsules per plant was significantly increased due to the different treatment combinations. Higher Number of capsules per plant (49.80) was recorded significantly higher in application of Phosphorus (P) @ $40 \mathrm{~kg} / \mathrm{ha}+$ Potassium (K)@20 kg/ha. $\mathrm{T}_{1}$ and $\mathrm{T}_{5}$ were statistically at par with $\mathrm{T}_{2}$. The more number of capsules per plant under higher Phosphorus doses might be due to proper availability of $\mathrm{P}$ at reproductive phase when plant needs more energy. These findings are similar with Thentu et al. (2014). Favorable enhance in levels of phosphorus significantly increased the yield attributing characters of sesame like number of capsules/plant Shelke et al. (2014). Higher uptake of nutrients viz., potassium and higher dry matter accumulation and translocation might be attributed to reproductive plant parts was reported by Thakur et al., (2015) in sesame.

Table 4: Influence of Phosphorus and Potassium levels on leaf area index in Sesame

\begin{tabular}{|c|c|c|c|c|c|}
\hline \multirow[t]{2}{*}{ Treatments } & \multicolumn{5}{|c|}{ Leaf area index } \\
\hline & 15 DAS & 30 DAS & 45 DAS & 60 DAS & 75 DAS \\
\hline 1. $40 \mathrm{~kg} \mathrm{P} / \mathrm{ha}+30 \mathrm{~kg} \mathrm{~K} / \mathrm{ha}$ & 0.16 & 0.74 & 6.57 & 7.31 & 7.33 \\
\hline 2. $40 \mathrm{~kg} \mathrm{P} / \mathrm{ha}+20 \mathrm{~kg} \mathrm{~K} / \mathrm{ha}$ & 0.18 & 0.76 & 6.58 & 7.57 & 8.56 \\
\hline 3. $40 \mathrm{~kg} \mathrm{P} / \mathrm{ha}+10 \mathrm{~kg} \mathrm{~K} / \mathrm{ha}$ & 0.15 & 0.74 & 5.25 & 6.58 & 7.08 \\
\hline 4. $30 \mathrm{~kg} \mathrm{P} / \mathrm{ha}+30 \mathrm{~kg} \mathrm{~K} / \mathrm{ha}$ & 0.16 & 0.50 & 4.69 & 5.81 & 6.94 \\
\hline 5. $\quad 30 \mathrm{~kg} \mathrm{P} / \mathrm{ha}+20 \mathrm{~kg} \mathrm{~K} / \mathrm{ha}$ & 0.17 & 0.56 & 5.45 & 5.95 & 6.96 \\
\hline 6. $30 \mathrm{~kg} \mathrm{P} / \mathrm{ha}+10 \mathrm{~kg} \mathrm{~K} / \mathrm{ha}$ & 0.12 & 0.36 & 4.59 & 5.65 & 5.23 \\
\hline 7. $20 \mathrm{~kg} \mathrm{P} / \mathrm{ha}+30 \mathrm{~kg} \mathrm{~K} / \mathrm{ha}$ & 0.09 & 0.35 & 3.39 & 4.28 & 4.78 \\
\hline 8. $20 \mathrm{~kg} \mathrm{P} / \mathrm{ha}+20 \mathrm{~kg} \mathrm{~K} / \mathrm{ha}$ & 0.15 & 0.56 & 3.65 & 4.78 & 5.42 \\
\hline 9. $20 \mathrm{~kg} \mathrm{P} / \mathrm{ha}+10 \mathrm{~kg} \mathrm{~K} / \mathrm{ha}$ & 0.09 & 0.30 & 3.09 & 3.15 & 4.00 \\
\hline $\mathrm{SEm} \pm$ & 0.03 & 0.06 & 0.45 & 0.57 & 0.76 \\
\hline $\mathrm{CD}(\mathrm{P}=0.05)$ & - & 0.17 & 1.36 & 1.72 & 2.27 \\
\hline
\end{tabular}

Table 5: Influence of Phosphorus and Potassium levels on yield, yield attributes and Oil content in Sesame.

\begin{tabular}{|l|l|l|l|l|l|l|}
\hline \multicolumn{2}{|l|}{ Treatments } & \multicolumn{6}{|l|}{ At harvest } \\
\cline { 3 - 8 } & $\begin{array}{l}\text { Capsules } \\
\text { per plant } \\
\text { (No.) }\end{array}$ & $\begin{array}{l}\text { Seeds per } \\
\text { capsule } \\
\text { (No.) }\end{array}$ & $\begin{array}{l}\text { Test } \\
\text { weight } \\
(\mathbf{g})\end{array}$ & $\begin{array}{l}\text { Seed yield } \\
(\mathbf{k g} / \mathbf{h a})\end{array}$ & $\begin{array}{l}\text { Biological } \\
\text { yield } \\
\text { (kg/ha) }\end{array}$ & $\begin{array}{l}\text { Oil content } \\
\mathbf{( \% )}\end{array}$ \\
\hline $\mathbf{1 .} \quad 40 \mathrm{~kg} \mathrm{P} / \mathrm{ha}+30 \mathrm{~kg} \mathrm{~K} / \mathrm{ha}$ & 40.40 & 51.33 & 3.82 & 311.67 & 1771.60 & 47.62 \\
\hline $\mathbf{2 .} \quad 40 \mathrm{~kg} \mathrm{P} / \mathrm{ha}+20 \mathrm{~kg} \mathrm{~K} / \mathrm{ha}$ & 49.80 & 56.40 & 3.90 & 361.00 & 2002.15 & 50.53 \\
\hline $\mathbf{3 .} \quad 40 \mathrm{~kg} \mathrm{P} / \mathrm{ha}+10 \mathrm{~kg} \mathrm{~K} / \mathrm{ha}$ & 36.87 & 49.67 & 3.47 & 297.67 & 1729.03 & 41.75 \\
\hline $\mathbf{4 .} \quad 30 \mathrm{~kg} \mathrm{P} / \mathrm{ha}+30 \mathrm{~kg} \mathrm{~K} / \mathrm{ha}$ & 31.67 & 49.27 & 3.35 & 292.00 & 1656.20 & 43.18 \\
\hline $\mathbf{5 .} \quad 30 \mathrm{~kg} \mathrm{P} / \mathrm{ha}+20 \mathrm{~kg} \mathrm{~K} / \mathrm{ha}$ & 39.87 & 50.07 & 3.48 & 299.00 & 1753.93 & 41.58 \\
\hline $\mathbf{6 .} \quad 30 \mathrm{~kg} \mathrm{P} / \mathrm{ha}+10 \mathrm{~kg} \mathrm{~K} / \mathrm{ha}$ & 29.73 & 48.93 & 3.10 & 281.33 & 1597.60 & 40.00 \\
\hline $\mathbf{7 .} \quad 20 \mathrm{~kg} \mathrm{P} / \mathrm{ha}+30 \mathrm{~kg} \mathrm{~K} / \mathrm{ha}$ & 30.67 & 47.60 & 3.17 & 270.00 & 1557.73 & 41.97 \\
\hline $\mathbf{8 .} \quad 20 \mathrm{~kg} \mathrm{P} / \mathrm{ha}+20 \mathrm{~kg} \mathrm{~K} / \mathrm{ha}$ & 34.40 & 49.87 & 3.19 & 271.67 & 1579.37 & 43.40 \\
\hline $\mathbf{9 .} \quad 20 \mathrm{~kg} \mathrm{P} / \mathrm{ha}+10 \mathrm{~kg} \mathrm{~K} / \mathrm{ha}$ & 29.53 & 45.07 & 3.00 & 254.33 & 1425.73 & 37.72 \\
\hline $\mathrm{SEm} \pm$ & 3.44 & 1.84 & 0.19 & 19.04 & 77.21 & 2.13 \\
\hline $\mathrm{CD}(\mathrm{P}=0.05)$ & 10.33 & 5.52 & 0.58 & 57.08 & 231.46 & 6.37 \\
\hline
\end{tabular}




\section{Number of seeds per capsules}

An insight into the data declared distinct variation of number of seeds/capsules due to of treatment differences. Number of seeds/capsule (56.40) was recorded significantly higher in application of Phosphorus (P)@40kg/ha + Potassium (K)@20 $\mathrm{kg} / \mathrm{ha}$. $\mathrm{T}_{1}$ was statistically on par with $\mathrm{T}_{2}$. Higher uptake of nutrients viz., phosphorus and potassium and higher dry matter accumulation and translocation might be attributed to reproductive plant parts. These results are found similar with the results of Patel (2017) in sesame.

\section{Test weight (g)}

Maximal 1000 seed weight was recorded $(3.90 \mathrm{~g})$ in application of Phosphorus (P) @ 40 kg/ha + Potassium (K)@20 kg/ha. $\mathrm{T}_{1}, \mathrm{~T}_{3}$ and $\mathrm{T}_{5}$ were statistically at par with $\mathrm{T}_{2}$. Ample amount of water at capsule and development stages resulted in the more accumulation of $\mathrm{P}$ and other nutrients ultimately in the grains which help to increase seed weight per plant. These results are similar with Khadse et al. (2017) in sesame. The test weight and size of the seed of sesame was increased under application of potassium. These results are in conformity with Jadav (2004) in sesame.

\section{Seed yield (kg/ha)}

Data on seed yield of sesame specified that significant differences due to different treatments combination of higher dose of inorganic fertilizers brought significant ehancement in seed yield over all the treatment combinations. The highest number of seed yield was recorded significantly superior seed yield (361 kg/ha) in application of Phosphorus (P)@ 40 kg/ha + Potassium (K)@ 20 kg/ha. $\mathrm{T}_{1}$ was statistically at par with $\mathrm{T}_{2}$. The beneficial effect of phosphorus on seed yield of sesame due to the stimulating effect of phosphorus on different yield attributing character viz., number of capsules/plant, number of seeds/capsule and test weight etc. These results are conformity with Choudhari and Patel (2007). Number of capsules per plant, number of seeds per capsule and test weight of seed has helped in enhancing the translocation of starch from source to sink and dry matter production, which promotes increasing the number of seeds per capsule. These results are in conformity with Bhosale (2009) in sesame.

\section{Biological yield (kg/ha)}

Data on Biological yield of sesame indicated significantly higher biological yield $(2002.2 \mathrm{~kg} / \mathrm{ha})$ value in application of Phosphorus (P) @ 40 kg/ha + Potassium (K)@20 kg/ha. With an increase in Phosphorus level biological yield increasing significantly. These results are similar to the findings of Hafiz et al., (2012). The Biological yield of sesame increased steadily with an increase in phosphorous levels. It might be attributed to higher dry matter accumulation and higher uptake of nutrients and translocation to reproductive plant parts. These results are in parallelism with Choudhari and Patel (2007) in sesame. The definite effect of potassium on Biological yield might be due to the effective role of potassium in photosynthesis and to its importance in cell elongation, carbohydrates synthesis more ever; higher nutrient uptake resulted in maximum plant height and number of branches per plant and eventually helped in increasing higher Stover yield. These results are in match up with those reported by Bhosale (2009) in sesame.

\section{Quality parameters}

Oil content

Data presented in Table 5. stated that the oil content in sesame indicated significant variation due to different treatments. The maximum oil content was recorded significantly highest in oil content (50.53\%) in application of Phosphorus (P)@ 40 $\mathrm{kg} / \mathrm{ha}+$ Potassium (K)@20 kg/ha. $\mathrm{T}_{1}$ was statistically on par with $T_{2}$. The favorable impact of phosphorus on seed yield of sesame might be due to the stimulating effect of phosphorus on different yield attributing character viz., number of capsules per plant, number of seeds per capsule and test weight etc. These results are conformity with Choudhari (2007). Progressive increase in level of potassium significantly increased the quality i.e. oil content $(46.75 \%)$. These results are equality with Jat et al. (2017) of sesame.

\section{Conclusion}

This study concluded that application of Phosphorus (P)@ @ 40 kg/ha plus Potassium (K) (a) $20 \mathrm{~kg} / \mathrm{ha}$ was found to be best that recorded the higher number of Capsules per plant, Seeds per capsule, Test weight, Seed yield, Biological yield. However, it produced significantly higher Oil content in sesame. 


\section{Acknowledgement}

I gratefully record my indebtedness to my advisor Dr. Umesha, C. for his parental affection, most valuable and timely guidance, concrete suggestions, constant encouragement, enormous help throughout my academic career and constructive criticism

\section{References}

Adisu, T., Anbesse, B., Tamene, D. 2020. Effect of Nitrogen and Phosphorus on Yield and Yield Components of Sesame (Sesamum Indicum L.) at Kamashi Zone of Benshangul Gumuz under Balanced Fertilizer. Advanced Techniques in Biology \& Medicine. 8:276-281.

Ahmad, F., Ahemad, J., Nawaz, H.,Abbas. M.W.,Shah, M A., Iqbal S., Mehmood, Z. and Ali, M. 2018. Influence of Sulphur and potassium levels on yield and yield attributes of sesame (Sesamum indicum L.). Research in Agriculture, Livestock and Fisheries. 5(2): 147- 150.

Bhosale, N. D. 2009. Effect of potash and sulphur on growth, yield and quality of sesame (Sesamum indicum L.). M.Sc(ag) thesis, Junagadh Agricultural University. Junagadh (Gujurat).

Chakraborty, A. 2013. Performance of summer sesame (Sesamum indicum L.) and estimation of economic and optimum doses of nitrogen and phosphorus in red and laterite soils of West Bengal. Journal of Crop and Weed. 9(1): 75-78.

Chang, A. H., Sheikh, S. A., Jamro, G. H., Jamro, G. M. and Memon, R. B. 2005. Growth and yield of sesame (Sesamum indicum L.) to different NP combinations. Indus Journal of Plant Sciences. 4(1): 32-37.

Choudhari, S. R. and Patel, D. B. 2007. Response of sesamum (Sesamum indicum L.) to different levels of phosphorous and sulphur under north Gujarat agro climatic conditions. Gujarat Agricultural University Research Journal. 32(12): 31-33.

De, P. S., Bhale V. M. and Khadse V. A. 2013. Quality and Economics of Summer Sesame (Sesamum indicum L.) as influenced by irrigation and Nutrient Levels. International Journal of Bio-resource and Stress Management. 4(2):369-371.

Gomez, K. A and Gomez, A. A. 1984. Statistical procedures for agricultural research. $2^{\text {nd }}$ edition.

Hafiz, S. I. and El-Bramawy, M. A. S. 2012. Response of sesame (Sesamum indicum L.) to phosphorus fertilization and spraying with potassium in newly reclaimed sandy soils. International Journal of Agricultural Science Research. 1(3): 34-40. throughout the course of this research work to the final shaping of manuscript and all the faculty members of Department of Agronomy for valuable suggestions and constant guidance throughout the course of this research work.

Jadav, D. P. 2004. Effect of different levels of sulphur and potash on grain and oil yields of sesame. M.Sc.(agri) Thesis submitted to J.A.U. Junagadh.

Jadhav, S. R. and Pawar, G. R. 2015. Effect of nitrogen, phosphorus and biofertilizers on growth, yield and quality of summer sesamum (Sesamum indicum L.) International Journal of Tropical Agriculture. 33(2):475-480.

Jahan, N., Alam, A. B. M. S., Mitu, A. S., Habib, M. A. and Rahman, M. S. 2019. Effect of Phosphorus on growth and yield of sesame, Research in Agriculture livestock and fisheries. 6(2): 245- 251.

Jat, R., Naga, S. R., Choudhary R and Mohammad, I. 2017. Effect of potassium and Sulphur on Quality of sesame (Sesamum indicum L.). International Journal of Microbiology and applied science. 6(4): 1876-1878.

Khadse V. A., Ghatol P. U. and Bhale V. M. 2017. Performance of Summer Sesame under Different Irrigation Scheduling and Nutrient Levels Vidarbha Region. International Journal of Current Microbialogy and Applied Science. 6(11): 1988-1993.

Malik, M. A., Saleem, M. F., Cheema, M. A. and Ahmed, S. 2003. Influence of different nitrogen levels on productivity of sesame (Sesamum indicum L.) under varying planting patterns. Int. J. Agric. Biol. 5(4): 490-492.

Okpara, D. A., Muoneke, C. O. and Ojikpong T. O. 2007. Effects of nitrogen and phosphorus fertilizer rates on the growth and yield of sesame (sesamum indicum L.) in the southeastern rainforest belt of Nigeria. Nigerian Agriculture Journal. 38: 1-11.

Pagal, A. K., Singh, A. P., Behera, S. and Meher, C. 2017. Effect of Differrent Levels of Sulphur and Phosphorus on Growth and Yield Attributes of Sesamum. International Journal of Current Microbiology and Applied Science. 6(11): 3278-3285.

Patel H. A. and Raj A. D. 2017. Nutrient content as well as uptake of summer sesame as affected by nitrogen, phosphorous and biofertilizers under South Gujarat condition. International Journal of Chemical Studies. 5(6): 01-04.

Rahman Abdel A. El Mahdi. 2008. Response of sesame to nitrogen and phosphorous fertilization in Northen Sudan. Journal of Applied Biosciences. 8(2):304-308. 


\section{Priyadarshini et al.}

Rajiv, Singh, D. P. and Prakash, H. G. 2012. Response of sesame (Sesamum indicum L.) varieties to sulphur and potassium application under rainfed condition. International Journal of Agricultural Sciences. 8(2): 476478.

Sarkar, R. K. and Pal, P. K. 2005. Effect of crop geometry, fertility level and nipping on physiological parameters in relation to productivity of sesame (Sesamum indicum L.). Indian Journal of Agricultural Sciences. 72: 70-73.

Shehu, H. E., Kawari, D and Sandabe, M. K. 2010. Effect of N, and $\mathrm{K}$ fertilizer on yield, content and uptake of N,P and $\mathrm{K}$ by Sesame. International Journal of Agriculture and Biology. 37(3): 602-604.

Shelke R. I, Kalegore N. K and Wayase K. P. 2014. Effect of levels of phosphorus and Sulphur on growth, yield and quality of sesame (Sesamum indicum L.). World Journal of Agricultural sciences. 10(3):108-111.

Thakur, A. K., Pradhan, A., Patel, R. K. and Kumar, P. 2015. Effect of different Nitrogen, Phosphorus and Potassium levels on sesame (Sesamum indicum L.) in Bastar Plateau of Chatisgarh. The Bioscan. 10(3): 1241-1243.
Thentu, T. L., Nawlakhe, S. M, Mankar, D. D., Shrinivasrao, M. and Bhonde, G. V. 2014. Growth, Yield and Quality of Summer Sesame as Influenced by the Fertilizer and Sulphur Levels. Journal of Soil and Crops. 24(1): 143147.

Unde G. B., Suryavanshi V. P. and Shinde R. S. 2017. Optimization of spacing and Fertilizer Levels on Growth of Sesame (Sesamum indicum L.). International Journal of Current Microbialogy and Applied Science. 6(12): 27932796.

Uzun B, Arslan I, Furat E. 2008. Variation in fatty acid compositions, oil content and oil yield in a germ plasm collection of sesame (Sesamum indicum L.). Journal of the American Oil Chemists' Society. 85, 1135-1142.

Younis, M., Shah, S. Inamullah, R. Gul, A. Jalal, F. Khalil, I. Hussain and M.A. Fahad. 2020. Effect of phosphorus and sulphur on yield and yield components of sesame. Sarhad Journal of Agriculture, 36(2): 722-728. 